\title{
A szorítóujjas burgonyaültető gép adagolórendszerén a burgonyára ható erővektorok vizsgálata
}

\section{Investigation of the Force Vectors Acting on the Potato in the Clamping Finger Type Dosing System of a Potato Planter}

\author{
Ilyés Szilárd, ${ }^{1}$ Pásztor Judit ${ }^{2}$ \\ ${ }^{1}$ Sapientia Erdélyi Magyar Tudományegyetem, Marosvásárhelyi Kar, Gépészmérnöki Tanszék. \\ Marosvásárhely, Románia, ilyes.szilard@ms.sapientia.ro \\ ${ }^{2}$ Sapientia Erdélyi Magyar Tudományegyetem, Marosvásárhelyi Kar, Gépészmérnöki Tanszék. \\ Marosvásárhely, Románia, pjudit@ms.sapientia.ro
}

\begin{abstract}
The operational accuracy of the dosing system of the potato planting machine influences the planting plant spacing, and indirectly the crop yield. The operating accuracy depends on the design of the dosing system, its kinematics and the forces acting on the planting tubers. This dissertation presents the force vectors acting on the potato in the dosing system of the guided clamping finger type potato planting machine and their spatial motion during the dosing process. Examination of the vectors reveals the improved possibilities of tuber fixation.
\end{abstract}

Keywords: potato planter, clamping-fingers, guide rail, dosing device, vector.

\section{Összefoglalás}

A burgonyaültető gép adagolórendszerének működési pontossága befolyásolja az ültetési tőtávolságot és egyben a lehetséges terméshozamot. A müködési pontosság az adagolórendszer konstrukciójától, annak kinematikájától és az ültetési gumókra ható erőktől függ. A dolgozat bemutatja a vezérpályás szorítóujjas burgonyaültető gép adagolórendszerében a burgonyára ható erővektorokat és azoknak a térmozgását az adagolási folyamat során. A vektorok vizsgálata feltárja a gumó rögzítésének fejlesztési lehetőségeit.

Kulcsszavak: burgonyaültető gép, vezérpálya, szorítóujj, adagolószerkezet, vektor.

\section{Bevezetés}

Az agrártudományokat kiszolgáló mezőgazdasági gépészet a gyakran egyszerűnek tűnő műszaki megoldások fejlesztésével egyértelműen hozzájárul a már létező munkagépek munkaminőségi paraméteri javításához.

A vezérpályás szorítóujjas adagolórendszerű burgonyaültető-gép Kelet-Európában terjedt el, a néhai csehszlovák iparnak köszönhetően.

A gép adagolószerkezetét és müködését az 1. ábra szemlélteti [1, 2]. Az 1-es ültetőtárcsa körmozgást végez, láncáttételeken és egy Norton-sebességváltón keresztül kapja a hajtását a talajhajtású meghajtókerékről. Az ültetőtárcsára

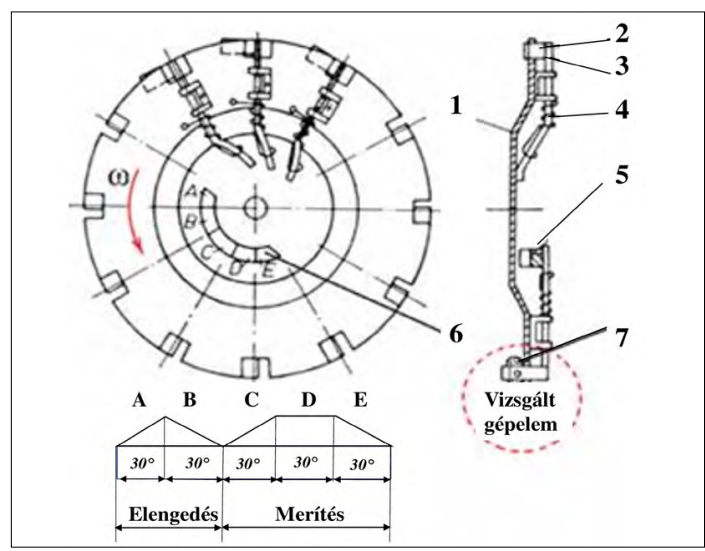

1.ábra. Szorítóujjas adagolórendszer [1] 
általában 12 darab 2-es szorítóujj van rögzítve. A szorítóujjak a 3-as tengelyeik körül elfordulnak a 4-es torziós rugó ellenében. Az elfordulást az 5-ös bütyök vezérli, így a szorítóujj rögzíti a 7-es gumót. A vezérlést a 6-os vezérlőpálya végzi.

A vezérlőpálya a szorítóujjakat a gumótartályba merüléskor csukja, felfelé haladva nyitja, majd a gumót megszorítva kiemeli, körbeszállítja, és az ejtőcsatorna fölött újra nyitva, a gumókat elengedi. Ez a folyamat az 1. ábrán követhető. A gumó a csoroszlya által nyitott barázdába kerül.

\section{Gumókra ható erővektorok helyzeté- nek elemzése a körforgás során}

A $C_{M}$-tömegközpontú gumókra ható erővektorok a 2. ábrán követhetők. Az 1-es pozícióban a szorítóujj rögzíti a gumót, a 1-2-3. pozíciókban a gumó szállítása történik. A 3-as pozícióban az ujj elengedi a gumót. A 4-es pozícióban zár az ujj.

A vizsgálat során az alábbi egyszerüsítéseket alkalmazzuk [3]:

- A gumó teljes kört ír le a tárcsával, de a valóságban elmarad a 3-4. szakasz (1. ábra).

- Elhanyagoljuk a tárcsaöböllyuk geometriáját a tárcsán [4] és a légellenállást.

- A gumókat gömb formájúnak tekintjük.

$\mathrm{Az} \mathrm{O}_{\mathrm{d}} \mathrm{XYZ}$ derékszögü koordinátarendszerben $r$ sugarú, $\phi=\phi(t)$ [rad] elfordulási szöggel jellemzett, $C_{M}$-pontba koncentrált $\mathbf{R}$ eredő erővektor a $\mathbf{G}$ súlyerő, az $\mathbf{F}_{\mathbf{c}}$ centrifugális erő, az $\mathbf{F}_{\mathbf{p}}$ szorítóujj nyomóerejének vektoriális összege:

$$
\begin{aligned}
& \mathbf{R}=\mathbf{G}+\mathbf{F}_{\mathbf{c}}+\mathbf{F}_{\mathbf{p}}[\mathrm{N}], \\
& \mathbf{G}=m \cdot g[\mathrm{~N}], \\
& \mathbf{F}_{\mathbf{c}}=m \omega^{2} r[\mathrm{~N}], \\
& \mathbf{F}_{\mathbf{p}}=k \cdot \theta / l[\mathrm{~N}],
\end{aligned}
$$

ahol: $m$ a gumó tömege [kg];

$g$ a gravitációs gyorsulás $\left[\mathrm{m} / \mathrm{s}^{2}\right]$;

$\omega$ a szögsebesség [rad/s];

$r$ a $C_{M}$-pontok távolsága a forgásponttól, [m];

$k$ a torziós rugó karakterisztikája [m/rad];

$\theta$ a szorítóujj nyitási szöge [ $\left.{ }^{\circ}\right][5]$;

$l$ a szorítóujj hossza a forgási tengely és a burgonyát támasztó pont között [m].

A G súlyerő közvetve függ a gumó m(dt) tömegétől.

$\mathrm{Az} \mathbf{F}_{\mathrm{c}}$ centrifugális erő függ a gumó $\mathrm{m}(d t)$ tömegétől, és a szögsebességtől.

Az $\mathbf{F}_{\mathbf{p}}$ nyomóerő 3. ábrán követhető, a 2-es ujjal rászorítja a 3-as gumót az 1-es tárcsa síkjára.

A (1-4)-es összefüggések mindegyikében a gumó $\mathrm{d}_{\mathrm{t}}$ átmérője (2. ábra) befolyással van a szorítóuj-

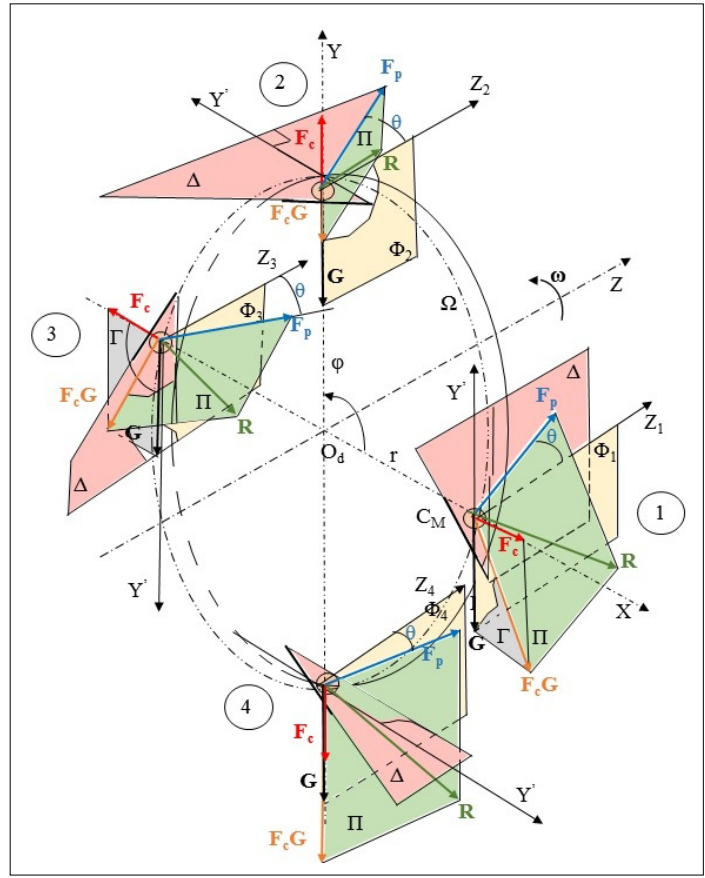

2. ábra. $A C_{M}$-pontban ható erők síkok szerinti ábrázolása



3. ábra. A szorítóujj hatása a $C_{M}$-pontban

jak $\theta$ nyitási szögére, amely egy teljes körbefordulás alatt állandónak tekinthető. Tehát az $\mathbf{F}_{\mathbf{p}}$ vektor $\theta$ ' merőleges szárú szöge is állandó, értéke $0<\theta^{\prime}<\pi / 2$ között van. A gyakorlatban a szorítóujj $\theta$ nyitási szöge kisebbnek tekinthető a $\pi / 2$ maximális elméleti értéknél.

A $C_{M}$ bármely $i=\overline{1,4}$ pozíciójában (pl. $\mathrm{i}=2$, ha $\phi=\pi / 2)$, a $\mathbf{G}$ vektor és a $C_{M} Z_{i}$ változó tengelyek meghatározzák a $\Phi_{i}$ (sárga) párhuzamos síkokat (2. ábra) [6]. A 2-es szorítóujj (3. ábra) és annak az 1-es tárcsára eső vetülete meghatározza a $\Delta$ (piros) forgássíkot (2. ábra). Az $\mathbf{F}_{\mathbf{c}}$ és $\mathbf{G}$ erők a $\Gamma$ (szürke) síkot határozzák meg, amely párhuzamos az $\mathrm{O}_{\mathrm{d}} \mathrm{XY}$ tárcsasíkkal. Az $\mathbf{F}_{\mathbf{c}}$ és $\mathbf{G}$ erők eredője 
az $\mathbf{F}_{\mathbf{c}} \mathbf{G}$ erő. Az $\mathbf{F}_{\mathbf{c}} \mathbf{G}$ és $\mathbf{F}_{\mathbf{p}}$ vektorok meghatározzák a $\Pi$ (zöld) síkot, eredőjük az $\mathbf{R}$ vektor. Az $\mathbf{R}$ vektor irányítása a szorítóujjtól a tárcsa felé történik, nagysága és iránya függ a másik három vektor tényezőitől.

Az $\mathbf{F}_{\mathbf{c}} \mathbf{G}$ eredőt az (5)-es összefüggés adja:

$$
F_{C G}=\sqrt{F_{c}^{2}+G^{2}+2 F_{c} G \cos \left(\varphi+\frac{\pi}{2}\right)} \text {. }
$$

A szorítóujj $\mathbf{F}_{\mathbf{p}}$ nyomóerővektorja benne van a $\Delta$ (piros) síkban, értéke állandó, iránya merőleges a $\Gamma$ (szürke) síkra.

Az $\mathbf{F}_{\mathbf{p}}$ nyomóerőnek az $\mathbf{F}_{\mathbf{p}} \sin \theta$ vetülete a tárcsa síkjára bármely $C_{M}$ pontban merőleges a sugárra (4. ábra). A vetületvektor a $C_{M}$-ponthoz tartozó sugárral egy állandó a szöget zár be (6):

$$
\alpha=\operatorname{arctg} \frac{F_{p} \sin \theta}{r}
$$

Mivel az $\mathbf{F}_{\mathbf{c}} \mathbf{G}$ is és az $\mathbf{F}_{\mathbf{p}}$ iránya és irányítása is változik a $\phi$ függvényében (2. ábra), az $\mathbf{R}$ eredő is a $\phi$ függvénye.

Vizsgálva az OZ-forgástengely szerint a $C_{M}$ pontokba ható $\mathbf{G}, \mathbf{F}_{\mathbf{c}}, \mathbf{F}_{\mathbf{p}}$ erőket, körmozgás esetén a következő forgástesteket kapjuk:

-0 és $G$ vastagság között változó síkgyürüt (5a. ábra); ,

-állandó $F_{c}$ vastagságú síkgyürüt (5b. ábra);

- $\rho$ görbe alkotójú homorú palástú gyűrűs forgástestet (5c. ábra), amelynek a sugarai $r$ és $O_{d}{ }^{\prime} A_{1}$, magassága $F_{p} \cos \theta$, (4. ábra). A sugarak közti összefüggés:

$$
o_{d}^{\prime} A_{1}=\sqrt{r^{2}+\left(F_{p} \sin \theta\right)^{2}}
$$

A $\theta$ szög nyitása nem éri el a határeseteket a szorítóujj konstrukciója és a minimális gumóátmérő miatt.

$\mathrm{Az} \mathbf{R}$ vektor forgásteste egy komplex térbeli alakzat, hiszen mind a mérete, mind a $\Pi$ (zöld) síkjának a tárcsával bezárt szöge változó a $\mathbf{F}_{\mathbf{c}} \mathbf{G}$ erővektorok változása miatt (3. ábra).

\section{Gumókra ható erővektorok helyzeté- nek elemzése egy pontba vetítve}

A $C_{M}$-tömegközpontú gumókra ható $\mathbf{G}, \mathbf{F}_{\mathbf{c}}, \mathbf{F}_{\mathbf{p}}$ erővektorok helyzetét a 6 . és 7 . ábra mutatja be.

Az $\mathbf{F}_{\mathbf{p}}$ erővektorok egy $\mathrm{O}_{\mathrm{d}} \mathrm{Z}$-vel párhuzamos $\mathrm{C}_{\mathrm{M}} \mathrm{Z}$-tengely körüli, $F_{p} \sin \theta$-sugarú kúppalástot (6. ábra) hoznak létre.

A $\mathbf{G}$ vektor mindig függőleges.

Az $\mathbf{F}_{\mathbf{c}}$ vektorok egy $F_{c}$ sugarú tömör (piros) kört alkotnak (7. ábra).

Állandó $d_{t}$ gumóátmérő esetén az $\mathbf{F}_{\mathbf{p}}$ erővektorok helyzetét a 6 . ábra mutatja be.

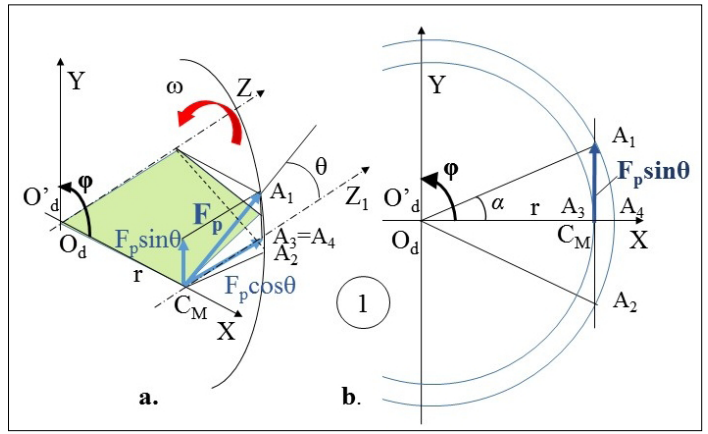

4. ábra. Az $\mathbf{F}_{\mathbf{p}}$ számítása a 1-es pozícióban

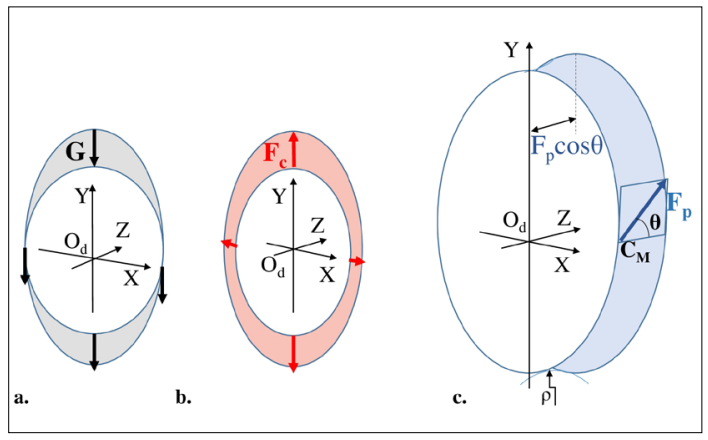

5. ábra. G, $\mathbf{F}_{\mathbf{c}}, \mathbf{F}_{\mathbf{p}}$ forgástestei

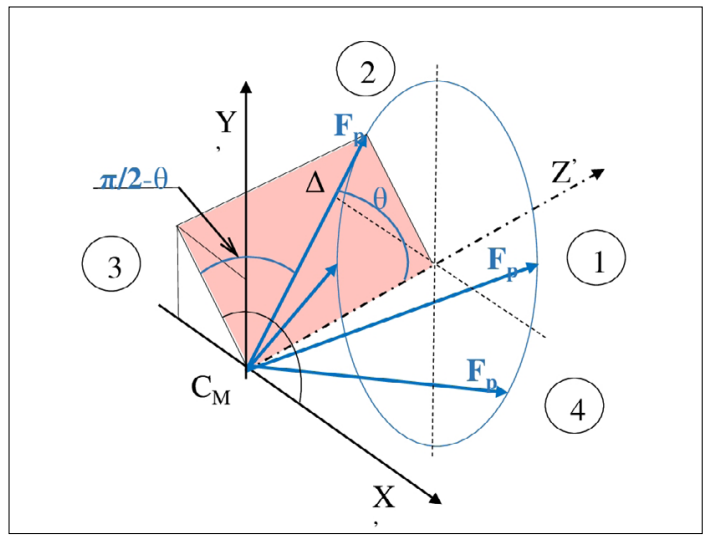

6. ábra. Az $\mathbf{F}_{\mathbf{p}}$ palást formája a CM-re vetítve

Észrevehető, hogy az eredő $\mathbf{F}_{\mathbf{c}} \mathbf{G}$ vektorok hegyei egy szintén $F_{c}$ sugarú $C_{R}$ kört írnak le, amelynek a középpontja a $\mathbf{G}$ vektor végpontjánál van (7. ábra).

Az $\mathrm{O}_{\mathrm{t}} \mathrm{GF}_{\mathrm{c}} \mathrm{G}_{\pi} \pi$ paralelogrammának az $O_{t} G$ oldala köré az $\mathbf{F}_{\mathbf{c}}$ hegyének körbeforgásával az $O_{t} G$ oldallal párhuzamos eltolások jönnek létre. A G nagysága szerint a $C F_{c}$ és $C_{R}$ körök kölcsönös helyzete határozza meg az $\mathbf{F}_{\mathbf{c}} \mathbf{G}$ eredő erő kiterített felületét. 


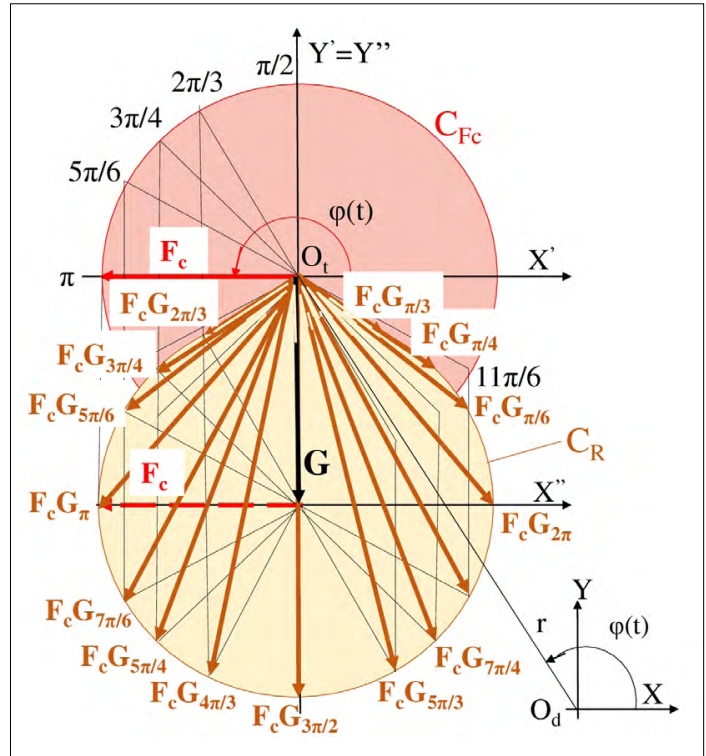

7. ábra. $A C_{M}$ pontban ható $\mathbf{F}_{\mathbf{c}}$ és $\mathbf{G}$ ábrázolása

Az erővektorok sík- és térbeli grafikai formáit elemezve észrevehető, hogy bármely $C_{M}$-pontba koncentrált változó vektorok értékein és irányításán nem lehet tetszés szerint változtatni a gumó jobb megtartása érdekében.

A gumó jobb megtartásán az $\mathbf{F}_{\mathbf{p}}$ nyomóerő $\theta$ ’ szögének a csökkentése tud segíteni. Erre lehetőség a támasztó elemek geometriai formái, a támasztóujj $l$ hossza és a $k$ rugókarakterisztika tökéletesítése. Ívelt ujj esetében a $\theta=m\left(\widehat{Z^{\prime} C_{M} F} p\right)$ a nyitási szög (3. ábra) folyamatosan csökken az ujj hossza mentén. Így bármely gumóval való érintkezési pontban az $\mathbf{F}_{\mathbf{p}}$ nyomóerő $\theta$ ' eltérési szöge kisebb lesz a szorítóujj eredeti $\theta$ nyitási szögéhez képest.

Tovább gondolva a lehetőségeket a gumómegtartás érdekében: az ívelt szorítóujj kanál alakúra képzésével figyelembe vehető a $C_{M}$ pontba ható $\mathbf{R}$ eredő vektor változása.

\section{Erővektorok helyzetének elemzése a körforgás során különböző gumóát- mérő esetén}

A munkagép működése során a kijuttatott gumók $d_{t}$ átmérője különböző. A szorító ujj $\theta$ nyitási szögének maximális értéke $\pi / 2$. Minimális értékét a legkisebb $d_{t}$ gumóátmérő határozza meg. Ebben az esetben az $\mathbf{F}_{\mathbf{p}}$ erővektorok kiterítése az $\mathrm{X}^{\prime} \mathrm{O}_{\mathrm{t}} \mathrm{Z}$ ' síkban az $\mathrm{F}_{\mathrm{p} 2} \mathrm{O}_{\mathrm{t}} \mathrm{F}_{\mathrm{p} 3}$ körcikk területet írja le (8.b. ábra). Az $\mathbf{F}_{\mathbf{p}}$ ' vektor $\mathrm{O}_{\mathrm{d}} \mathrm{Z}$ körüli rotációja során az $O_{t}^{\prime}$-pont az $O_{t}$ pozícióba, az $F_{p 1}$-pont az $F_{p 2}$ pozícióba kerül, az $F_{p 3}$ vektor pedig transzlációt végez, meghatározva az $T\left(F_{p 1} O_{t} F_{p 3}\right)$ keresztmetszetű gyürüs forgástestet.

Az $F_{p 2} O_{t} O_{d}$ és $F F_{p 1} O_{d}$ háromszögekből meghatározható a forgástest maximális $d$ vastagsága:

$$
d=\sqrt{r^{2}+F_{p}^{2}}-r
$$

Az $F_{p}$ sugarú $\mathrm{C}_{\mathrm{Fp}}\left(\mathrm{F}_{\mathrm{p} 2}, \mathrm{O}_{\mathrm{t}}, \mathrm{F}_{\mathrm{p} 3}\right)$ körív az X'O $\mathrm{Z}_{\mathrm{t}}$ 'síkban egy teljes $\mathrm{C}_{\mathrm{Fp}}\left(\mathrm{O}_{\mathrm{t}}, \mathrm{F}_{\mathrm{p}}\right)$ körnek a negyede. Ennek a körnek a síkja az $O_{t}$ pontban $r$ távolságra van az $O_{d}$ középpontú $r+d$ sugarú gömbben (8.a. ábra).

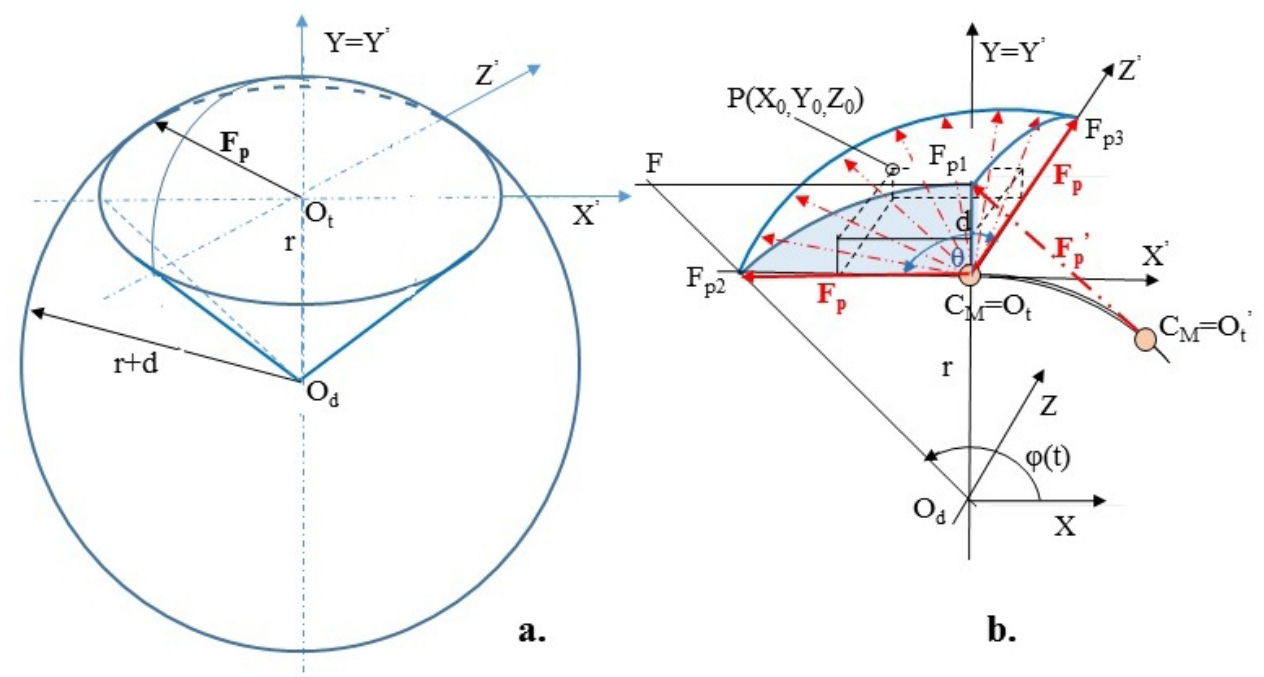


Ennek a gömbnek a részei az $\left(F_{p 1} F_{p 2}\right),\left(F_{p 1} F_{p 3}\right)$ és $\left(F_{p 2} F_{p 3}\right)$ negyedkörívek, amelyek egyben a $d$ magasságú gömbsüveg részei is. Tehát a három görbe az $F_{c}$ sugarú negyed gömbsüveget határozza meg (8.b. ábra). Az alkotó gömbsüveg középpontja $O_{d}$, sugara $r+d$, metsző körének sugara $\mathbf{F}_{\mathbf{c}}$, magassága $d$. Tehát az $\mathbf{F}_{\mathbf{c}}$ vektor forgásteste egy olyan gyürü, amelyet az $r+d$ sugarú gömbsüveg negyedrésze határoz meg. Az alkotók az $F_{p 1} F_{p 2}$ körív, az $O_{d} F_{p 1}=d$ maximális vastagság, és az $\mathrm{O}_{t} \mathrm{Fp}$. magasság. $\mathrm{Az}$ alkotók az $\mathrm{O}_{\mathrm{d}} \mathrm{Z}$ tengely körül $r$ sugárral forognak.

Az alkotó görbe egyenlete az $O_{d}$-ből húzott $r+d$ sugarú körív egyenlete (9), amelynek hosszát a $F_{p 1}$ és $F_{p 3}$ határolja be (10):

$$
Y^{2}+Z^{2}=(r+d)^{2}
$$

ahol:

$$
X=0, \quad r<Y<r+d, \quad 0<Z<F p_{3} .
$$

\section{Következtetés}

A szorítóujjas ültetőszerkezetre ható erővektorok grafikai tanulmányozása képet ad az erővektorok sík- vagy térbeli változásairól, és szemlélteti az adagolószerkezet működési határait.

A gumóra ható erővektorok nagysága függ a gumó tömegétől, közvetve gumó átmérőjétől. Az eredő erő nagysága függ az ültetőtárcsa elfordulási szögétől is.

$\mathrm{Az} \mathbf{F}_{\mathbf{p}}$ erővektorok a gumó $C_{M}$-tömegközéppontjába vetítve $\theta$ ' szögnyílású, egyenes kúp forgástestet alkotnak.

Az $\mathbf{R}$ eredő vektor a teljes körforgás alatt egy komplex forgástestet alkot, a változó irány és nagyság miatt. Az ábrázolása számítógépes grafikai módszer nélkül nehezen lehetséges.
A szorítóujjtárcsa közötti gumómegtartás függ a gumómérettől, a tárcsa szögsebességétől, a szorítószerkezet geometriájától és az $\mathbf{F}_{\mathbf{p}}$ nyomóerőtől. A szorítóujj geometriájának jó kialakításával, az állandónak tekintett nyomóerőnagyság mellett, a vektor irányát változtatva, a gumó jobb rögzítését lehetne elérni. Tehát a gumómegtartás javítására a szorítóujj fokozottabb hajlítása, ívelése javasolt. Az eredő $\mathbf{R}$ vektor változó iránya és nagysága indokolttá teszi a szorítóujj kanalasítását, öblösítését is a biztosabb gumómegtartás érdekében.

A dolgozat rámutat a vezérpályás szorítóujjas burgonyaadagoló-rendszer gumórögzítésének fejlesztési lehetőségeire.

\section{Szakirodalmi hivatkozások}

[1] Căproiu Ş., Sripnic V., Ciubotaru C., Babiciu P., Roș V.: Maşini agricole de lucrat solul, semănat şi întreţinerea culturilor. Editura Didactică şi Pedagogică, București, 1982.

[2] Zheng Z., Zhao H., Liu Z., He J., Liu W.: Research Progress and Development of Mechanized Potato Planters: A Review. Agriculture, 11/6. (2011) 521. https://doi.org/10.3390/agriculture11060521

[3] Rus F.: Mașini agricole pentru lucrările solului, semănat și intreținerea culturilor. Editura Universitatea Transilvania Brașov, Brassó, 1975.

[4] Ilyés Sz:: A szoritóujjas rögzítés geometriai és dinamikai elemzése a burgonyaültető gép esetében. XXVIII. Nemzetközi Gépészeti Konferencia, Székelyudvarhely-online, Románia, OGÉT 2020, 2020. 105-108. https://ojs.emt.ro/index.php/oget/article/view/207

[5] Jula A., Lateș M.: Organe de mașini. Universitatea Transilvania Brașov Kiadó, Brassó, 2004.

[6] Máté M.: Müszaki mechanika - kinematika. EME Kiadó, Kolozsvár, 2010. https://doi.org/10.36242/mtf-10 